Resumen por los autores, Swale Vincent y A. T. Cameron.

Universidad de Manitoba.

Nota sobre un reflejo inhibidor de la respiración en la rana y otros animales.

En todos los animales existen mecanismos reflejos que inhiben los movimientos respiratorios cuando la cabeza se sumerje en el agua. Los receptores de tales reflejos están situados probablemente en el epitelio de la membrana mucosa nasal. En adición los autores han encontrado algunas pruebas que demuestran que en la rana existe un mecanismo reflejo accesorio que depende de la oclusión de los orificios nasales externos y la cesación de la corriente de aire en los pasajes respiratorios. Ambos reflejos pueden entrar en acción cuando la rana está sumerjida.

Translation by Jose F. Nonidez

Carnegie Institution of Washington 
AUTHOR' ABSTRACT OF THIB PAPER ISSUED

BY THE BIBLIOGRAPHIC SERVICE, FEBRUARY 23

\title{
A NOTE ON AN INHIBITORY RESPIRATORY REFLEX IN THE FROG AND SOME OTHER ANIMALS
}

\author{
SWALE VINCENT AND A. T. CAMERON \\ Department of Physiology, Biochemistry, and Pharmacology, University of \\ Manitoba, Winnipeg, Canada
}

Some of the results stated for the frog in the present communication were read to the Scientific Club of Winnipeg on February 24,1914 . At that time we were not acquainted with any previous account of the phenomenon, but subsequently discovered Axenfeld's paper," published in 1911. This appears to be a preliminary communication and contains no references to literature. We have failed to find any subsequent communication by Axenfeld or any other author upon this reflex in the frog, and since Axenfeld does not appear to state fully the facts of the case, we have decided to make a brief communication at the present time.

Moreover, the observations on other animals made by several previous observers seem to have been overlooked by the most recent writers. Starling, writing in Schäfer's Text-book, ${ }^{15}$ says:

A pure expiratory reflex may also be brought about by gentle stimulation of the nasal mucous membrane of the rabbit, as by application of chloroform vapor. A similar expiratory pause is caused in many animals by dipping the nose into water, or even by plunging the lower half of the body into water (Tauchreflex). The temperature of the water is of no influence on the results of the experiment. Frédericq ${ }^{9}$ has shown that a specially long expiratory pause may be produced in a diving animal, such as the duck, by allowing a stream of water to flow on its beak. The teleological importance of these reflex cessations of respiration, which have been classed together by Miescher-Rüsch ${ }^{13}$ as apnoea spuria is obvious.

We have found other references to the authors here quoted, including a paper by Foà modifying Miescher's classification of apnoeal reflexes. We have, unfortunately, not been able to 
consult the original papers of these authors, and from the references we cannot be certain how far they have dealt with the precise points with which we are most concerned.

\section{A. THE FROG}

The normal respiration of the frog has been fairly completely studied. A summary of the known facts is given by Baglioni. ${ }^{3}$ It is sufficient to remark here that a large share in the function of respiration is borne by the skin, the lungs providing an accessory mechanism consisting of two separate movements, a) that of the mouth with the lungs closed off and, $b$ ) the true lung movements, the latter only occurring at certain intervals. The movements with which we are concerned in this paper are those occurring in the throat and nostrils. (For an account of the normal respiration compare also Willem. ${ }^{16}$ )

Two different kinds of external influences have been described as affecting the movements in question. Graham Brown, ${ }^{6}$ who gives a good account of the literature, deals chiefly with the influence of the nervous system and the labyrinth, but mentions certain external factors producing inhibition, such as shaking of the animal, a blow on the nose, stimulation of the skin, etc. He does not mention the effect of immersion in water or of plugging the nostrils. Axenfeld, ${ }^{1}$ who seems to have been the first to describe specifically the immersion apnoea in the frog, attributes the phenomenon to a definite stimulation of the nerve endings of the nasal mucous membrane by means of water. Some of the earlier observers referred to by Graham Brown describe an apnoeal reflex in the frog due to various afferent impulses arising from different parts of the body surface.

The immersion apnoea is one which must have been familiar to naturalists for a long time. The moment that a frog becomes completely immersed in water, the respiratory movements cease, and remain in abeyance as long as the animal continues to be immersed. The most elementary observation shows that cessation of breathing occurs at the moment that both nostrils touch the water. Our observations were directed chiefly toward determining the nature of the stimulus which inhibits the respiratory movements. 
Axenfeld comes to the conclusion that the nasal mucous membrane is stimulated specifically by air and by water, and that the stimulation calls forth in one case movements of breathing, and in the other inhibition of these. He states that 20 per cent acetic acid destroys the reflex by damaging the mucous membrane of the nostril; if a frog is immersed after such treatment it continues to breathe, filling its mouth with water.

He also states that the inhibitory reflex is not altered after section of the first division of the fifth nerve with its nasal branch.

We have carried out the following series of experiments:

1. Several frogs were treated with 20 per cent acetic acid, following Axenfeld's directions, and using his precaution of plugging the mouth with absorbent cotton while the nostrils were being treated with the acid, in order to prevent more extensive damage. We found that the proceeding interferes with the normal respiration. The animal can no longer breathe properly, even in air. When such an animal is placed in water it is true that it continues the movements of respiration, but this is rendered possible by the opening of the mouth to some extent and not through true nasal breathing. The interference with breathing in the air is probably due to swelling of the epithelium and excess of mucus in the nasal cavity, and in this case also the animal breathes through the mouth.

We have repeatedly observed that during free-air breathing when through any cause the nasal passages become obstructed, after a while the animal will continue breathing by occasionally opening and closing the mouth.

2. More complete destruction of the epithelium of the nasal passage can be produced by the actual cautery. We have done this with several frogs, and if the passage of the nose be kept free something approaching a regular respiration will go on for some time. This, however, ceases instantly on immersing the animal in water. It has been pointed out to us that the cautery will not destroy the epithelium of the deep recesses of the nasal cavity.

3. Early in our experiments it was noticed that plugging the nostrils with blunt seekers or by placing the fingers over the 
nasal apertures, immediately stops the movements of the floor of the mouth. The inhibition is temporary, and lasts from eight to fifteen seconds. Mechanical stimulation of the interior of the nostril does not produce this effect, nor does mechanical stimulation of the skin in the neighborhood of the nostril. A weak electrical stimulation in the same neighborhood produces no effect, but a strong stimulation with induced current causes the animal to throw back its head, and this type of action, as observed by Graham Brown and others, checks the respiratory movements. But it is interesting to note that when the head is thrown back or pushed back by the hand, in either case there occurs closure of the nostrils concurrently with cessation of respiration, and stimulation of the skin of the back will induce throwing back of the head, closing of the external nares, and stoppage of respiration.

These changes in some ways simulate the posture reflex observed in the duck by Huxley (see below). It should therefore be pointed out here that when a frog is immersed in water or when the nostrils are plugged, no such change of posture need necessarily occur, and does not usually so occur, so that the reflex is not due to this cause.

4. The following experiment was carried out with two frogs: Fine, accurately fitting cannulae were inserted into the nostrils after cauterizing. The animal was then immersed with the extremities of the cannulae communicating with air; so long as the cannulae were not plugged by mucus, and did not by pressure mechanically occlude the nasal passages (these errors were specifically guarded against in the cases observed), respiration went on normally, and no inhibition could be induced such as those described as similar to the postural reflex (it being no longer possible to close the nares). On removing such tubes from the nostrils while the frog was under water, breathing stopped immediately.

Repetition of this experiment with a number of other frogs gave less satisfactory results, owing to the difficulty of keeping the cannulae free from mucus, etc. In some cases where the cautery had enlarged the aperture of the nostril considerably so 
that the cannulae did not completely occlude it, immersion of the animal, snout-end last, caused immediate cessation of respiratory movements, apparently through the entry of water into the nostrils round the outside of the cannulae.

In all the above experiments similar effects were produced by immersion in water, whether the animal was immersed snout first or snout last, except in cases where the mucous membrane of the nostrils had been damaged, when change of posture produced an effect in some animals, this being almost certainly due to increased or decreased plugging of the nostrils with mucus.

5. Cannulae were inserted into the nostrils of an intact animal; the respiratory movements were seriously affected, but after some minutes an imperfect kind of respiration began. The free ends of the cannulae were then immersed in water, and after several seconds the same imperfect respiratory movements recommenced, although only water could be taken in. This occurred even when the nostrils were also submerged.

All these experiments were carried out with $R$. pipiens from Illinois.

\section{Conclusions}

Apparently Axenfeld is right in supposing that the most important factor in the submersion stoppage of respiratory movements is a specific stimulation of the nasal mucous membrane by contact with water. This is supported by our experiments nos. 4 and 5, and is not definitely contradicted by no. 2 . It may be observed in this place that this inhibition of the respiratory movements is more pronounced and permanent in the frog than in other classes of animals, since, as shown by experiments carried out in this laboratory, ${ }^{7}$ the animal can live for many weeks under water, and during this time makes no attempt at respiratory movements, the floor of the mouth remaining permanently in the expiratory position.

In addition to the reflex described above, there appears to be another and quite separate one, caused by plugging the nostrils (cf. experiment 3). We are tempted to suggest that the sense of resistance brought about by the impeded air flow and experi- 
enced through the muscular sense of the throat muscles acts as the afferent stimulus for the reflex.

\section{B. BIRDS}

The respiratory reflexes in the duck have been dealt with in a series of papers by Frances M. Huxley. ${ }^{10,11,12}$ This observer, who makes no reference to the work of Frédericq, noted that respiration in the duck always ceased when the head and neck were immersed in water. In her conclusions she says $\left({ }^{10}, \mathrm{p} .152\right)$ :

Thus submersion of a duck's head gives rise to complete apnoea followed by a compensatory hyperpnoea. Submersion of the end of the bill does not produce this; submersion of the external nares does so only to a certain degree. For its complete production entire immersion of the glottis, the anterior portion of which lies $2.5 \mathrm{~cm}$. behind the posterior border of the external nares, is required.

In her second paper published on the same date she seems to have somewhat altered her opinion. Here she states: "As soon as the mucous membrane of the nostrils, etc., comes in contact with the water, a reflex apnoea is produced" (11, p. 174).

Her detailed description of experiments points to the latter view as being the more correct. Both with immersion of nostrils and immersion of the whole head there was a comparable percentage of cases where one or two respiratory movements were made after immersion.

We have made several immersion experiments with the duck, and we believe complete immersion of the nostrils (and not necessarily of the whole head) is sufficient to induce apnoea.

Doctor Huxley appears to assume that the mechanism is a reflex from the mucous membrane of the nostril, as Axenfeld assumed in the case of the frog, but her experiments did not eliminate the possibility of a mechanical factor, such as we have stated to be efficient in the latter animal. Such a mechanical factor, however, does not appear to be in operation in the case of the duck.

Plugging the nostrils does not interfere with the normal breathing in the duck, but this is partly due to the fact that the 
animal breathes through the mouth. Surrounding the mouth cavity with water and subsequently plugging the nostrils, does not interfere with respiratory movements. Further, immersion of the head in water while the nostrils are plugged with the fingers has no effect, although on removing the fingers from the nostrils while the head is still under water all respiratory movements are immediately inhibited. This seems to us conclusive evidence that in the duck a fluid contact with the mucous membrane of the nostril is essential to the reflex.

We can fully confirm Frédericq's observation that pouring water over both the nostrils will bring about the apnoea, although the mouth is freely exposed to air. Further, we find that a stream of water directed through the nostrils produces the same effect. Plugging one nostril with the finger and directing a stream of air (under pressure) against the other induce the reflex, but this may be due to distention of the air sacs, which produces apnoea, according to Baer. ${ }^{2}$ Stimulation by introducing a solid object into the nostril (such as wires, india-rubbẹr tubing, etc.) is not effective.

It thus appears that the apnoeal reflex in the bird is of a similar nature to the more important one in the frog.

The postural reflex fully described by Huxley and by Paton ${ }^{14}$ in the duck may be easily demonstrated, and we have no further observation to offer upon this phenomenon. Whether there is a similar reflex in the frog we cannot yet be sure. What we at first thought to be a postural reflex in that animal seems connected with closure of the nostrils, and is probably something different.

We have carried out a series of experiments upon the pigeon. Immersion of the nostrils in water or direction of a stream of water upon the nostrils immediately stops the respiratory movements. A stream of air under pressure produces the same effect as in the duck, but this may be due to distention of air sacs (see above). On the other hand, plugging the mouth and nostrils and mechanical and electrical stimulation are not effective. 


\section{MAMMALS}

According to Huxley, Beau ${ }^{4}$ in 1860 observed that when a $\mathrm{dog}$ is immersed in water it immediately ceases breathing, and this was confirmed by Paul Bert ${ }^{5}$ in 1870. Beau attributed the cessation to reflex action from contact of water with the respiratory orifices, while Bert considered it due to voluntary movement.

We have found that the reflex can be readily demonstrated in the white rat.

We have shown that if the snout of the non-anaesthetized animal be immersed in water at body temperature (to avoid effect of cold), even if part of the mouth remains in contact with air, immediately the nostrils are immersed they are closed and respiration ceases.

Precisely the same occurs with the anaesthetized animal, and the result can easily be recorded by the graphic method. The reflex is very definite, and-with a short immersion lasting a few séconds only-appears to persist for some seconds after removal of the snout from water.

The observation upon the anaesthetized animal is sufficient to negative any suggestion of voluntary action.

Further observations showed that a stream of air under slight pressure stops the respiration, while plugging the nostrils and mouth and mechanical and electrical stimulation do not do so.

The same results are obtained with the anaesthetized rabbit.

Although we are not yet prepared to discuss fully the nature of the reflex in mammals, we think that it is probably of the same nature as that in the duck.

\section{GENERAL SUMMARY}

In all vertebrates there appear to be reflex mechanisms which inhibit the respiratory movements when the animal's head is submerged beneath the surface of water. The receptors for these reflexes are probably situated in the epithelium of the nasal mucous membrane. In addition we have adduced some evidence that in the frog there is an accessory reflex mechanism 
depending upon the plugging of the nostrils and stoppage of the flow of air through the respiratory passages. Both these may come into play when the frog is submerged.

Doctor Herrick has pointed out to us that there are "four different types of innervation of the nasal region; the functional limitations of no one of which have been clearly shown. These are:

1. Trigeminal nerve endings.

2. Olfactory nerve.

3. The vomeronasal nerve, with the same type of peripheral endings as the olfactory, but limited to the vomeronasal organ (Jacobson's organ) peripherally and with a special part of the olfactory bulb (the bulbus accessorius) centrally.

4. The nervus terminalis-peripheral endings unknown and central endings independent of the olfactory bulb.

"Ayers (Jour. Comp. Neur., June 15, 1919, vol. 30, 323) has suggested some of the physiological problems here. The terminal nerve is found in all vertebrates from fishes up and is therefore probably not specifically concerned with air breathing. On the other hand, Jacobson's organ and its nerve are well developed in air breathers. Their reduction in birds may account for some of the peculiarities of these animals."

Since we shall find it impossible to pursue this line of investigation any further, we can only hope that the above observations may at any rate serve the purpose of suggesting a field for comparative physiological research.

Some of the experiments above described were carried out by Mr. K. J. Austmann under our direction. 


\section{LITERATURE CITED}

1 Axenferd, D. 1911 . Die Bedeutung der Nasenschleimhaut für den Respirationsakt der Amphibien. Zentralb. f. Physiol., Bd. 25, S. 329-31.

2 BAER, M. 1897 Zur physiologischen Bedeuting der Luftsäcke bei Vögeln. Biol. Zentralb., Bd. 17, S. 282, quoted by Baglioni, Ergeb. d. Physiol., 1911, Bd. 11, S. 558.

3 Baglioni, S. 1911 Zur vergleichenden Physiologie der Atembewegungen der Wirbertiere. Ergeb. f. Physiol., Bd. 11, S. 526.

4 Besu 1860 Recherches sur la mort par submersion. Arch. gén. de médecine, $5^{\circ}$ série, T. 16, quoted by Huxley, Quart. J. Exp. Physiol., 1913, vol. 6, p. 147 .

5 Bert, Padr 1870 Physiologie de la Respiration, quoted by Huxley (ibid.)

6 Brown, T. Graram 1909 Die Atembewegungen des Frosches und ihre Beeinflussung durch die nervösen Zentren und durch das Labyrinth. Arch. f. d. ges. Physiol., Bd. 130, S. 193.

7 Cameron, A. T., and Brownlee, T. I. 1915 On an accumulation of gas in the tissues of the frog as a result of prolonged submersion in water. Quart. J. Exp. Physiol., vol. 9, p. 231.

8 Fon, C. 1911 Nuove ricercho sull' apnea e sull' automatismo del centro respiratorio. Arch. di. Fisiol., vol. 9, pp. 453-76, quoted by Baglioni, q. v., p. 581 .

9 Frederice 1893 Arch. f. Physiol., Leipzig, Suppl. S. 65, quoted by Starling (q. v.).

10 Hoxuey, Frances M. 1913 On the reflex nature of apnoea in the duck in diving: I. The reflex nature of submersion apnoea. Quart. J. Exp. Physiol., vol. 6, pp. 147-57.

11 Ibid., II. Reflex postural apnoea. Ibid., pp. 159-82.

12 On the resistance to asphyxia of the duck in diving. Ibid., pp. 183-96.

13 Miescher-Rüsch. 1885 Arch. f. Physiol., Leipzig, 1885, S. 355, quoted by Starling (q. v.).

$14 P_{\text {ATON }}$, D. N. 1914 The relative influence of the iabyrinthine and cervical elements in the production of postural apnoea in the duck. Quart. J. Exp. Physiol., vol. 6, 197-207.

15 Starling, E. H. 1900 Mechanism of the respiratory movements. Schäfer's Text-book of Physiology, vol. ii, p. 305.

16 Willem, V., 1919 Les mouvements respiratoires de la grenouille. Arch. néerl. de physiol., vol. 3, pp. 315-48, through Physiol. Abstracts, vol. 4, pp. 265-6. 